\title{
Microbial Risk Assessment of the Contamination Level of Bovine Carcasses Slaughtered in an Abattoir in Maramureş County
}

\author{
Raul RAT ${ }^{1}$, Sorin Daniel DAN ${ }^{1 *}$, Sorin PLATON ${ }^{2}$, Marian MIHAIU ${ }^{1}$, Oana REGET ${ }^{1}$, Alexandra TĂBĂRAN ${ }^{1}$ \\ ${ }^{1}$ Department of Animal Production and Food Safety, University of Agricultural Sciences and Veterinary \\ Medicine, Faculty of Veterinary Medicine, 3-5 Mănăștur Street, 400372, \\ Cluj Napoca, Romania \\ ${ }^{2}$ Sanitary Veterinary and Food Safety Directorate Cluj Napoca, 1 Mărăşti Square, 400012, Cluj Napoca \\ Corresponding author: sorindan@usamvcluj.ro
}

Bulletin UASVM Veterinary Medicine 72(1) / 2015,

Print ISSN 1843-5270; Electronic ISSN 1843-5378

DOI:10.15835/buasvmcn-vm: 11103

\begin{abstract}
Cattle carcasses may be contaminated during the flow diagram process with a wide variety of spoilage and pathogenic microorganisms with different origin, from various sources (soil, water, tools, knives, feces, operators), but only few of them will be able to develop in the new ecosystem conditions, and from these only a small proportion will eventually start the spoilage processes. Taking into account the above mentioned we aimed to perform a microbiological risk evaluation focusing on the aerobic plate count (APC), E. coli count, Enterobacteriaceae count and the identification of Salmonella spp. The research material was represented by 60 surface samples of refrigerated beef, collected during January-December 2013, in a slaughterhouse in Maramureş County. In order to evaluate the contamination level of the carcasses we used the following standardized methods: SR ISO 4831/2003 for aerobic plate count, SR ISO 21528-2/2007 for Enterobacteriaceae count, SR IS016649-2/2007 for Escherichia coli and SR ISO 6579/AC/2006 for Salmonella spp. identification. The statistical data obtained concerning the slaughtering process revealed that the total microbial load was between $2.5-5.67 \log \mathrm{cfu} / \mathrm{cm}^{2}$. These elevated values indicate non-compliance regarding the good hygiene practices and good manufacturing during the technological flow. From the total collected samples analyzed, the germs belonging to Enterobacteriaceae family, exceeded the maximum admitted level in $10.8 \%$, respectively E. coli presented values between $0.5-1.9 \log \mathrm{cfu} / \mathrm{cm}^{2}$. Samples were negative for S. enteritidis and S. typhimurium.
\end{abstract}

Keywords: cattle carcasses, microbial risk assessment, slaughterhouse.

\section{INTRODUCTION}

Bacterial microflora from the carcass is largely dependent on the conditions in which the animals were reared, slaughtered and on carcass processing conditions in the processing units. An initial contamination occurs at the time of the first section, later contamination is due to aerosols and the dust generated after skinning, to the contact with the operators hands or by the contact of the skin with the subcutaneous connective tissue (Zweifel et al., 2008). During processing, carcass microbial load increases through germ contamination from the instruments used: hooks, chains, knives, saws, work surfaces etc. (Gill et al., 1998; Murraz et al., 2001). There is much debate about the possibility of obtaining sterile meat, but in the meat from healthy animals and processed in strict compliance with the rules of hygiene, the microbial load is very low, below $10^{2}$ cfu $/ \mathrm{cm}^{2}$, of which $1 \%$ or sometimes even $10 \%$ can be developed under refrigerated conditions (Ingram et Roberts, 1976). In the case of pork meat, initial microflora differs from that found in cattle, due to different processing steps at these 
species. After blanching processes, hair removal, singeing, microbial load is reduced significantly, below $10^{3}$ or even $10^{2} \mathrm{cfu} / \mathrm{cm}^{2}$, however after further processing steps recontamination occurs. Another major source of carcass surfaces' contamination is the evisceration. Rapid cooling of the carcasses at low temperatures, increased speed of air flow may result in a reduction of bacterial population, while mild cooling will allow the growth and development of germs. As a result, strict compliance with the cooling chain is vital, as it must ensure not only extend validity period, but also that these products are safe for the consumer. Therefore, in this study, we aimed to evaluate the degree of carcasses contamination with germs performing the following determinations: the total number of germs, the germ load of the Enterobacteriaceae family, E. coli $\beta$-glucuronidasepositive and Salmonella genus.

\section{MATERIALS AND METHODS}

The research material was represented by 60 samples of cattle and pigs carcasses harvested in January-December 2013 from a slaughterhouse in Maramures County. A number of 5 samples from the surface of the chilled cattle carcasses and 5 samples from pork carcasses surface were taken each month. The samples were analyzed in the laboratory of Food Inspection and Control of the FMV Cluj Napoca. To assess the degree of contamination of carcasses the following standard microbiological methods were used: determination the total number of germs (APC) SR ISO 4833/2003, determination of the number of bacteria belonging to the Enterobacteriaceae family (SR ISO 215282/2007), identification of Salmonella spp. (SR EN ISO 6579/AC/2006), identification of Escherichia coli beta glucuronidase-positive (SR ISO 16649$2 / 2007)$. The results were analyzed statistically and mathematically using the Origin 8.5 program, using the ANOVA single factor categorical analysis system.

\section{RESULTS AND DISCUSSION}

From the results obtained it was found that the aerobic plate count (APC) was between 3.0-2.5 $\log \mathrm{cfu} / \mathrm{cm}^{2}$ with an average of $02 \pm 2.7$, namely the number of bacteria of the Enterobacteriaceae family ranged between 1.9-1.0 log $\mathrm{cfu} / \mathrm{cm}^{2}$ with a mean value between $04 \pm 1.4$. All samples were within the maximum allowed (Fig. 1). Regarding E. coli, mean values ranged from $0.35-1.54 \log \mathrm{cfu} /$ $\mathrm{cm}^{2}$, with a mean of $0.95 \pm 0.5 \mathrm{log} \mathrm{cfu} / \mathrm{cm}^{2}$. For the samples collected in January, no bacteria of the Salmonella genus were identified.

Aerobic plate count (APC) in February was between 3.7-2.9 $\log \mathrm{cfu} \mathrm{cm}^{2}$ with an average of $0.3 \pm 3.1 \log \mathrm{cfu} / \mathrm{cm}^{2}$. The level of contamination with bacteria from the Enterobacteriaceae family ranged from 2.1-1.2 log $\mathrm{cfu} / \mathrm{cm}^{2}$ with an average of $0.34 \pm 1.65$ and E. coli ranged between $0.35-1.54$ $\log \mathrm{cfu} / \mathrm{cm}^{2}$, with a mean of $0.98 \pm 0.5 \log \mathrm{cfu} /$

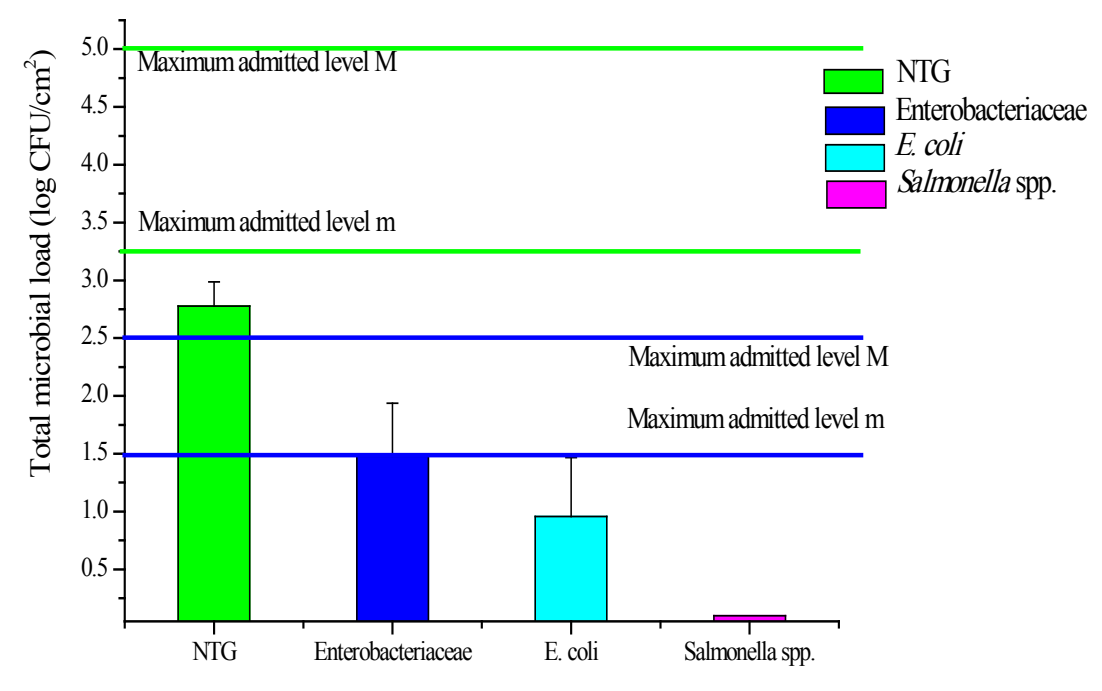

Fig. 1. Aerobic plate count, Enterobacteriaceae, E. coli and Salmonella spp. medium load at the surface of bovine carcasses during January 
$\mathrm{cm}^{2}$. Because they complied with good hygiene practices (GHP) and good manufacturing practices (GMP) on all processes it can be observed that the mean values of surface contamination of cattle carcasses with microorganisms are lower, fitting within the maximum limits.

Studies published by Zweifel et al. (2008) highlighted the values of surface contamination of cattle carcasses with microorganisms from the Enterobacteriaceae family between $3.8 \mathrm{log} \mathrm{cfu} /$ $\mathrm{cm}^{2}$, noticing an increased value that exceeded the maximum allowed limit of $2 \log \mathrm{cfu} / \mathrm{cm}^{2}$.

The mean value of aerobic plate count (APC) on the surface of cattle carcasses, in March showed slightly higher values than in February, falling between 3.6-5.5 log $\mathrm{cfu} / \mathrm{cm}^{2}$, with a mean of $4.44 \pm 0.85 \log \mathrm{cfu} / \mathrm{cm}^{2}$ ( $\mathrm{p}>0.05$ ). Analyzing the results, we found that 2 samples exceeded the maximum allowed of $5.0 \mathrm{log} \mathrm{cfu} / \mathrm{cm}^{2}$ (Fig. 2). These high values denote non-compliance regarding the code of good manufacturing and hygiene practices (GHP, GMP), along the processing flow of slaughtering in cattle. The level of contamination with Enterobacteriaceae was between 1.6-2.5 log $\mathrm{cfu} / \mathrm{cm}^{2}$, with a mean of $0.33 \pm 1.95 \log \mathrm{cfu} / \mathrm{cm}^{2}$ being in the limit, while the load of E. coli ranged between $0.6-1.6 \log \mathrm{cfu} \mathrm{cm}^{2}$, with an average of $1.03 \pm 0.5 \log \mathrm{cfu} / \mathrm{cm}^{2}$.

Analyzing the results it was found that aerobic plate count (APC) in April was 5.2-2.8 log cfu/ $\mathrm{cm}^{2}$ with an average range of between $0.95 \pm 4.02$ $\log \mathrm{cfu} / \mathrm{cm}^{2}$. From the total amount of samples analyzed, one of them was not within the limit, which shows that did not complied with good hygiene practices and have taken corrective measures for reducing microbial contamination, the same problem as in March where two of the samples analyzed exceeded the maximum limit. The level of contamination with bacteria from the Enterobacteriaceae family was between 2.1-1.5 $\log \mathrm{cfu} / \mathrm{cm}^{2}$, with a mean of $0.26 \pm 1.7 \log \mathrm{cfu} / \mathrm{cm}^{2}$. Regarding E. coli, mean values ranged from 1.2-04 $\log \mathrm{cfu} / \mathrm{cm}^{2}$, with a mean of $0.79 \pm 0.39 \log \mathrm{cfu} /$ $\mathrm{cm}^{2}$.

The aerobic plate count (APC) on the surface of cattle carcasses in June showed slightly higher values than in May ( $p>0.05$ ), falling between $5.67-4.5 \log \mathrm{cfu} / \mathrm{cm}^{2}$ average of $0.54 \pm 5.11 \mathrm{log} \mathrm{cfu} /$ $\mathrm{cm}^{2}, 3$ samples exceed the maximum permissible limit of $5.0 \log \mathrm{cfu} / \mathrm{cm}^{2}$. The load of germs from Enterobacteriaceae family showed values between $3.48-2.3 \mathrm{log} \mathrm{cfu} / \mathrm{cm}^{2}$ average of $0.46 \pm 2.77 \mathrm{log}$ $\mathrm{cfu} / \mathrm{cm}^{2}, 3$ of the samples analyzed exceeded the maximum permissible limit of $2.5 \mathrm{log} \mathrm{cfu} / \mathrm{cm}^{2}$. These elevated values show that the slaughterhouse did not respect the strict requirements of GMP and GHP program implementation. In case the limits of the parameters regarding technological process hygiene criteria, the measures aimed at improving hygiene in the unit and increase the

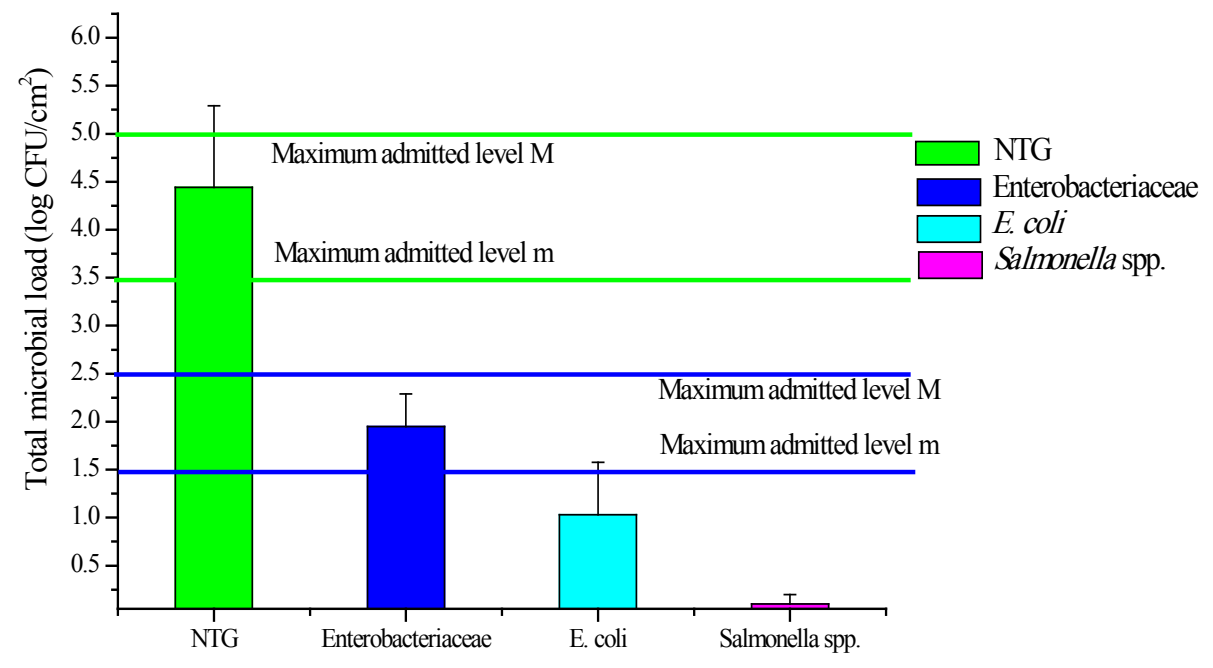

Fig. 2. Aerobic plate count, Enterobacteriaceae, E. coli and Salmonella spp. medium load at the surface of bovine carcasses during March 
frequency of sampling until their classification in the appropriate values. The mean load of E. coli were higher than in previous months, ranging between 1.9-1.2 log $\mathrm{cfu} / \mathrm{cm}^{2}$ with an average of $0.38 \pm 1.6 \log \mathrm{cfu} / \mathrm{cm}^{2}$ (Fig. 3).

In July it was found that the aerobic plate count (APC) ranged between 4.0-3.0 log cfu/ $\mathrm{cm}^{2}$ with an average of $0.37 \pm 3.5 \log \mathrm{cfu} / \mathrm{cm}^{2}$, respectively the number of bacteria from the Enterobacteriaceae family ranged between 1.0-2.3 log cfu/ $\mathrm{cm}^{2}$ with an average of $0.63 \pm 1.46 \log \mathrm{cfu} / \mathrm{cm}^{2}$. Regarding E. coli, the mean values ranged between 0.3-0.45 log cfu/ $\mathrm{cm}^{2}$, with a mean of $0.61 \pm 0.27 \log \mathrm{cfu} / \mathrm{cm}^{2}$. For the samples analyzed in July there were no identified bacteria from the Salmonella genus. It can be seen in the results presented above that in July they took corrective action, thus avoiding the growth of higher values of microbiological contamination of cattle carcasses, observing strict hygiene standards throughout the technological flow. All samples analyzed were within the maximum allowed. Studies by Murraz et Gadden (2001) showed values of carcasses contamination in bovine with Enterobacteriaceae between $0.70 \pm 2.80 \mathrm{log} \mathrm{cfu} /$

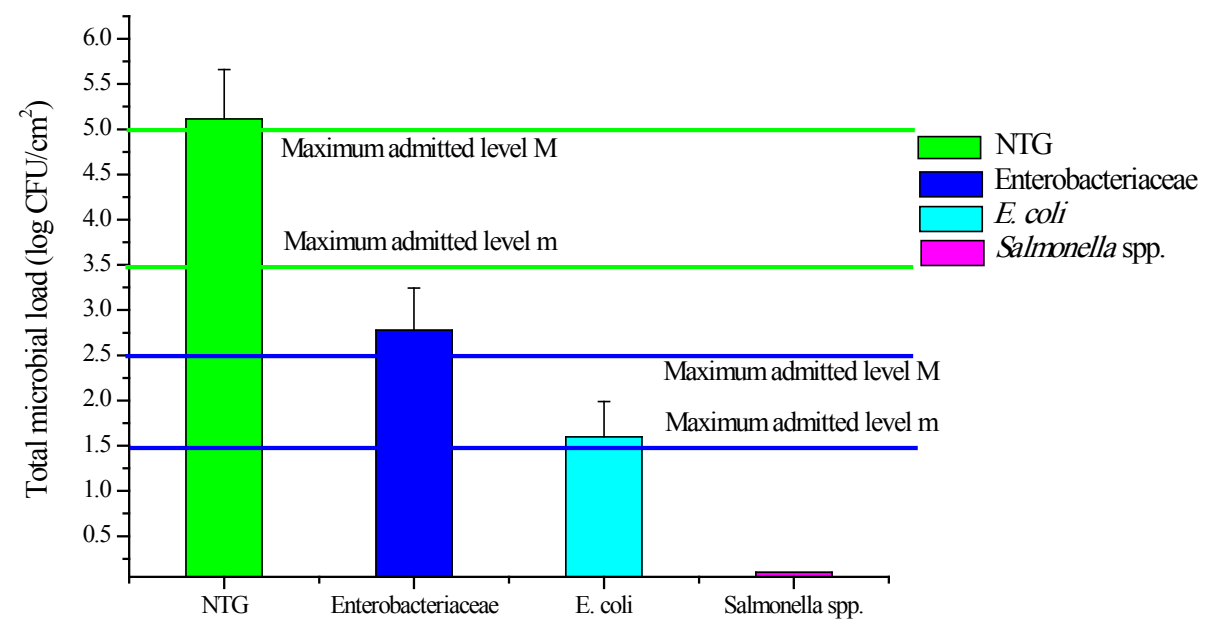

Fig. 3. Aerobic plate count, Enterobacteriaceae, E. coli and Salmonella spp. medium load at the surface of bovine carcasses during June

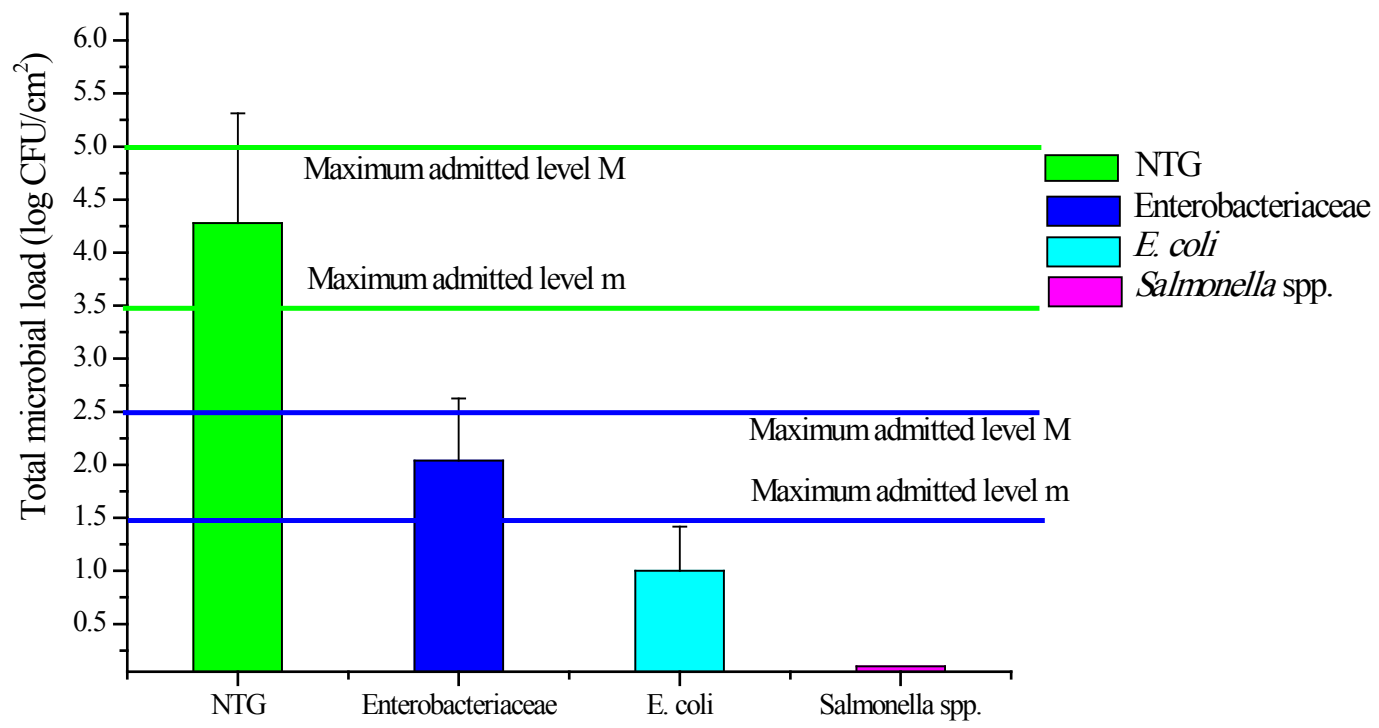

Fig. 4. Aerobic plate count, Enterobacteriaceae, E. coli and Salmonella spp. medium load at the surface of bovine carcasses during September 
$\mathrm{cm}^{2}$, these elevated values reveals a breach of good hygiene practices (GHP) and good manufacturing practices (GMP) throughout the technological flow. From the statistical processing of the results obtained in August, the value of TC from cattle carcasses surface have ranged between 3.6-2.0 $\log \mathrm{cfu} / \mathrm{cm}^{2}$ with an average of $0.66 \pm 3.1 \log \mathrm{cfu} /$ $\mathrm{cm}^{2}$. The average level of Enterobacteriaceae load was between 1.48-1.0 log cfu/ $\mathrm{cm}^{2}$ with an average value of $0.66 \pm 3.1 \log \mathrm{cfu} / \mathrm{cm}^{2}$. Regarding $E$. coli the mean values ranged from $0.9-0.3 \mathrm{log} \mathrm{cfu} / \mathrm{cm}^{2}$ with an average of $0.21 \pm 0.55$. Following the results, we found that all the samples analyzed were within the limit, which means that they have complied with hygiene practices in all processes. Higher values of E. coli, on the level of contamination of the surface in cattle carcasses were reported by Sumner et al., 2003, which presented an average of $0.23 \pm 1.82 \log \mathrm{cfu} / \mathrm{cm}^{2}$.

Following the results obtained in September we found that the aerobic plate count (APC) was located between $5.7-3.0 \log \mathrm{cfu} / \mathrm{cm}^{2}$ with a mean value between $1.03 \pm 4.28 \mathrm{log} \mathrm{cfu} / \mathrm{cm}^{2}$. From the results obtained, one of the samples exceeded the maximum permissible limit being $5.0 \mathrm{log} \mathrm{cfu} /$ $\mathrm{cm}^{2}$. The load level of Enterobacteriaceae was between 2.6-1.3 log $\mathrm{cfu} / \mathrm{cm}^{2}$ with an average of $0.58-2.04 \mathrm{log} \mathrm{cfu} / \mathrm{cm}^{2}$ (fig. 4). It was found that the maximum allowed, $2.5 \log \mathrm{cfu} / \mathrm{cm}^{2}$, was exceeded in two samples. In accordance with Reg. 1441 (EC) / 2007 in the case of hygiene criteria parameters exceeding within the technological process, measures are taken to improve hygiene in the unit and increase the frequency of sampling to their classification in the corresponding values. Regarding E. coli load, values ranged between $1.2-0.5 \log \mathrm{cfu} / \mathrm{cm}^{2}$ with an average of $0.41 \pm 1.0$ $\log \mathrm{cfu} / \mathrm{cm}^{2}$.

In October the aerobic plate count (APC) was between 3.67-3 log cfu/ $\mathrm{cm}^{2}$ with an average of $0.31 \pm 3.31 \log \mathrm{cfu} / \mathrm{cm}^{2}$. The level of contamination with bacteria from Enterobacteriaceae family was in between 2.0-1.3 $\log \mathrm{cfu} / \mathrm{cm}^{2}$ with an average of $0.36 \pm 1.48$, while in the case of $E$. coli, mean values ranged from 0.4-0.6 log $\mathrm{cfu} / \mathrm{cm}^{2}$ with an average of $0.52 \pm 0.08 \log \mathrm{cfu} / \mathrm{cm}^{2}$. As they complied with good hygiene practices (GHP) and good manufacturing practices (GMP) for all processes, all samples analyzed were within the maximum allowed. In the case of the samples taken in October no Salmonella germs were identified. Higher values of microbial contamination were published by Ahmad et al. (2013), which in the case of $E$. coli showed values ranging between 2.81-3.51 log $\mathrm{cfu} / \mathrm{cm}^{2}$. Also $26 \%$ of all samples analyzed were positive for Salmonella, compared to samples examined by us, where all the samples analyzed were negative.

Medium aerobic plate count (APC) on the surface of cattle carcasses in December showed higher values than in November ( $p>0.05)$, ranging from 2.7-4.7 $\log \mathrm{cfu} / \mathrm{cm}^{2}$ with an average value

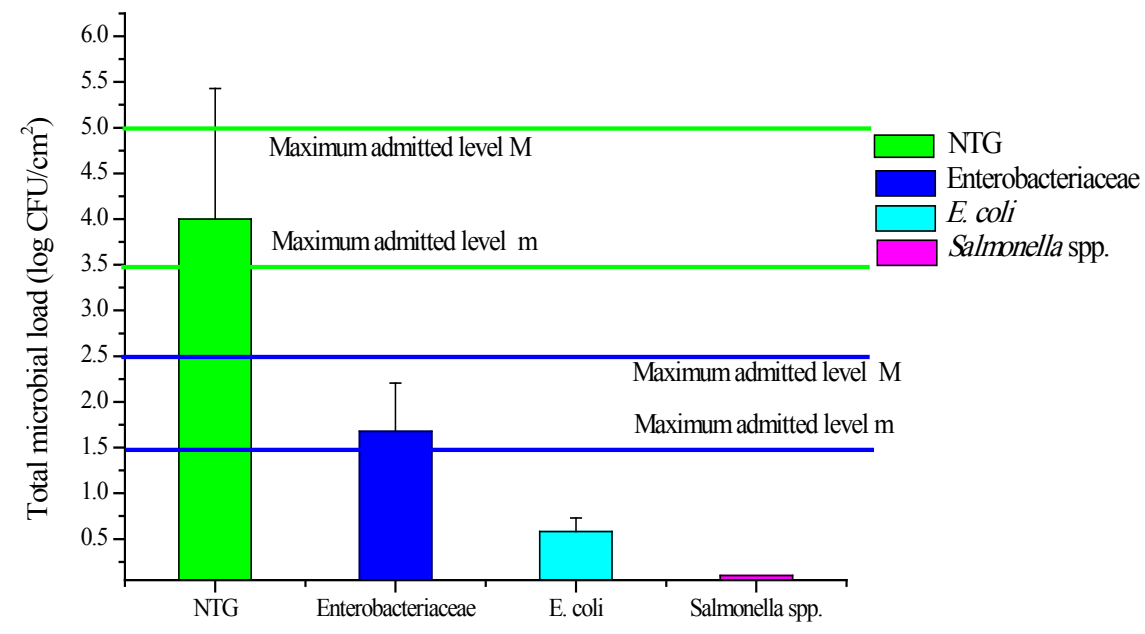

Fig. 5. Aerobic plate count, Enterobacteriaceae, E. coli and Salmonella spp. medium load at the surface of bovine carcasses during December 
of $1.43 \pm 4.0 \log \mathrm{cfu} / \mathrm{cm}^{2}, 2$ samples exceeded the maximum allowed. The load of Enterobacteriaceae germs showed values between 2.6-1.3 log $\mathrm{cfu} / \mathrm{cm}^{2}$ with an average of $0.52 \pm 1.67 \log \mathrm{cfu} /$ $\mathrm{cm}^{2}$, one of the samples analyzed exceeded the maximum allowed limit of $2.5 \log \mathrm{cfu} / \mathrm{cm}^{2}$. Elevated values regarding aerobic plate count and Enterobacteriaceae count was were reported by Dan et al., (2003), in a research regarding psychrotrophic microbial count. These elevated values show that the slaughterhouse did not respect the strict requirements of GMP and GHP program implementation throughout the flow diagram of cattle slaughtering, and at that time in Romania and EU it was a different food legislation, different by the new EU food legislation (e.g. Reg. CE 853/2004, Reg. CE 1441/2007). The average load with $E$. coli ranged between $0.8-0.4 \log \mathrm{cfu} /$ $\mathrm{cm}^{2}$ with a mean of $0.14 \pm 0.58 / \log \mathrm{cfu} / \mathrm{cm}^{2}$ (Fig. 5). Among the samples gathered in December no bacteria from the Salmonella genus were identified.

\section{CONCLUSION}

From the total collected samples analyzed aerobic plate count exceeded the maximum admitted level in case of $4.2 \%, 10.8 \%$ of germs belonging Enterobacteriaceae family exceeded the maximum admitted level, respectively $E$. coli presented values between 0.5-1.9 $\log \mathrm{cfu} / \mathrm{cm}^{2}$. These results indicate that good hygiene practices and good manufacturing practices were not respected all the time during the flow diagram of cattle slaughtering. We mention that germs belonging to Salmonella were not identified. The results are different from those published by Dan et al. (2011), regarding evaluation on pathogen load on bovine carcasses, when $5.56 \%$ of analyzed samples $(\mathrm{n}=36), 2$ were positive for Salmonella enteritidis.

\section{REFERENCES}

1. Ahmad MVD, Sarwar A, Najeeb MI, Anjum AA, Ali M A, Mansur N (2013). Assessment of microbial load of raw meat at abattoirs and Retail outlets. The Journal of Animal \& Plant Sciences 23(3):745-748.

2. Dan SD, Rotaru O, Răpuntean Gh, Mihaiu M, Zegrean G (2003). The dynamic of psychrotrophic microflora in beef during slaughtering process. Bul USAMV-CN Veterinary Medicine 60: 67-71.

3. Dan SD, Mihaiu M, Lăpuşan A, Mihaiu R, Taulescu C (2011). The Evaluation of the Pathogen Germ Load and Configuration at the Bovine Carcasses Destined for Public Consumption, Bulletin USAMV Veterinary Medicine 68(2):125-132.

4. Gill CO, Deslandes B, Rahn K, Houde A, Bryant J (1998). Evaluation of the hygienic performances of the processes for beef carcass dressing at 10 packing plants. Journal of Applied Microbiology 84:1050-1058.

5. Ingram M, Roberts TA (1976). The microbiology of the red meat carcass and the slaughterhouse. Royal Society of Health Journal 96:270-276.

6. Murraz KA, Gilmour A, RH Madden (2001). Microbiological quality of chilled beef carcasses in Northern Ireland: A Baseline Survey. J Food Prot.

7. Sumner J, Petrenas E, Dean P, Dowset P, West G, Wiering $R$, Raven G (2003). Microbial contamination on beef and sheep carcasses in South Australia, International Journal of Food Microbiology 81 (3):255-260.

8. Zweifel C, Fischer R, Stephan R (2008). Microbiological contamination of pig and cattle carcasses in different small-scale Swiss Abattoirs. Meat Sci 78(3):225-231.

9. *** Regulamentul (CE) nr. 1441/2007, al Comisiei din 5 decembrie 2007 de modificare a Regulamentului (CE) nr. 2073/2005 privind criterile microbiologice pentru produsele alimentare.

10. *** SR EN ISO 6579/2003, SR EN ISO 6579 AC/2009. Metoda orizontală pentru detectarea bacteriilor din genul Salmonella.

11. *** SR EN ISO 16649-2/2007. Metoda orizontală pentru numărarea Escherichia coli pozitivă la $\beta$-glucuronidază.

12. *** SR ISO 4833/2003. Metoda orizontală pentru enumerarea microorganismelor. Tehnica de numărare la $30^{\circ} \mathrm{C}$.

13. *** SR ISO 21528-2/2007. Metoda orizontală pentru enumerarea germenilor din familia Enterobacteriaceae. 